\title{
Exploring Beirut's instability through its informal mobility
}

\begin{abstract}
The present article addresses the transformations of Beirut, Lebanon's public transport system from its establishment in the 1890s until its disruption during the Lebanese civil war of 1975-1989. The civil war left the country with a weak state, weak planning, and ongoing implications including the emergence of informal mobility. Although informal mobility is a global phenomenon, Beirut provides an opportunity for its study in the context of instability, with implications for riders' spatial experiences. Within the framework of the mobility turn and mobility experiences, the present article explores the impact of the war-time divides on mobility in Beirut and the transition from a system operated under the auspices of the Ministry of Transportation and Public Works to one operated by private entities with politico-sectarian support. The article analyses the contextually embedded informal framework in terms of regulations, operations, negotiations, and Beirut's road infrastructure. To this end, the methodology comprises literature review, analysis of the available bus map, interviews with the Riders Rights NGO, and observations along selected bus routes. The article the basis for further exploring how the spatial experiences of riders in this informal system are affected by Beirut's post-war, divided configuration and securitization. The purpose of the article is to establish a basis for further investigating the system's potential for social integration within Beirut's fragmented and unstable context.
\end{abstract}

Keywords: Informal mobility, Beirut, spatial divides, securitization, infrastructure

\section{Introduction}

Lebanon's geopolitical position, alongside internal and external influences, gave rise to intermittent instability throughout its history down to the present. During the civil war of 19751989, Beirut was divided into east and west parts, its population segregated along politicosectarian differences, while the government and urban planning system were weakened. This instability led to disruptions of everyday life, which equally affected mobility (Adey et al., 2014: 11; Adams-Hutcheson, 2017). Such disruptions generated differentiated spatial experiences based on private car or public transport, while adaptations enabled people to continue their much-needed mobility despite instability. One such adaptation was the emergence of the informal bus system. The critical transportation situation in Lebanon, and the difficulty to provide an integrated public transport system, is reflected in reports by the UITP (2019), the World Bank (2016, 2017), UN-Habitat (2018), and the recent proposal to implement Bus Rapid Transit (BRT) without an indication of how the current informal bus system could be integrated (CDR, 2018).

Informal mobility based on informal transport plays a central role in cities worldwide yet remains tangential to academic research (Medeiros et al., 2018: 5). Literature on informal transport generally focuses on the Global South, referring to such forms of mobility as, for example, para-transit, third-world transport, intermediate technologies, or artisanal transport (Cervero, 2000: 3; Godard, 2008). However, empirical studies show that informal transport also exists in the Global North, relating informality to regulation, organization, and the economy (Cervero, 2000; Cervero \& Golub, 2007; Adey et al., 2014; Kumar, 2016; Buhr, 2017; Rekhviashvili \& Zgibnev, 2020). Further research is required to examine its implications within different urban contexts (Evans et al. 2018). In terms of the current informal mobility debates 
related to power relations, culture, and market influence, the scene of informal buses in Beirut is comparable to that in other cities globally. Yet, Beirut's case, with its contextually embedded aspects including its car-dominated, securitized, socially polarised, and unstable context (Nemeth, 2010; Mom et al., 2011; Mom, 2017; Mom \& Clarsen, 2017), can make an important contribution to our understanding of implications of instability on mobility. In particular, the present article explores spatial changes caused by the fragmented city, and their impact on the spatial experiences of the informal system's users.

The section that follows provides an overview of the role of mobility in everyday life and urban experiences, building on the mobility turn (Urry \& Sheller, 2006), with the purpose of examining mobility under instability. Then the characteristics of informal mobility are presented as a framework for analyzing Beirut's case. The article examines Beirut's public transport in its historical context and focuses on the shift or emergence of informal mobility following the civil war. Methodologically, in addition to the literature review and analysis of the existing bus map, the article builds on interviews with the Riders Rights NGO, conducted with both founders on 14 June 2018 and with one of them on 20 May 2019, 8 August 2019, and 3 March 2021. These interviews provided insights into the informal mobility system, its material and immaterial traits, and operation models. To demonstrate the differentiated spatial experience, the same journey from one location in an eastern suburb to the same destination, Hamra, in the west (Figure 1) is indicated with a car trajectory and by commuting using the available bus lines, with the required route interchanges and an exploration of the experience of getting off the bus at a stop (Mady, 2020).

\section{Mobility, informal mobility, and instability}

This section explains the importance of mobility and its lived experience, particularly in unstable contexts. It then specifically examines informal mobility and its traits as presented in the literature, with the purpose of framing the case study of Beirut. Regardless of the means of transport, mobility is a constituent of everyday life (de Certeau, 1984). Mobility contributes to spatial connectivity among people, objects and information (Salazar, 2018), and the everyday contextual experiences of "socialities, affinities, knowledge" (Buhr \& McGarrigle, 2017, 227228). Mobility adapts itself to circumstances, and is "something we learn to do and that requires a constant manipulation and re-adjustment of skills and knowledge” (Buhr \& McGarrigle, 2017: 232). In unstable contexts and in response to various threats, securitization affects social interaction by secluding streets, and both public and private urban spaces. Instability and securitization often result in the emergence of "militarized landscapes", which either physically or symbolically reduce or obstruct mobility (Nemeth, 2010: 2489; Nemeth \& Hollander, 2010). Furthermore, heightened security measures generate feelings of insecurity and fear, which may result in insular behaviour, even in the case of mobility (Nemeth, 2010; Blokland, 2017; Leese \& Wittendorp, 2018). Under instability, mobility by car could be favoured over that by public transport, since it allows for flexibility in route choice and dissociation from the public through an insular spatial practice (Alaily-Matar, 2008; Blokland, 2017; Farjalla et al., 2017). Note that simultaneously occupying the same urban space does not imply that people in that space-time engage in the same activities. By isolating themselves in micro-cultures, car users could cluster without interaction (Yip, 2016: 162). For instance, the co-presence of private cars and buses on the same road, in the context of which the bus riders remain unknown to each other, generates different perceptions of riders' profiles. The lack of participation in public transport results in a "public space so imputed with normative understandings of (in)appropriateness that they appear inaccessible to some” (Blokland, 2017: 559). Conversely, shared mobility contributes 
to the "co-constitution" of meanings to urban areas through the mode of transport, its subjects, and the public experience embedded in this system (Sheller, 2014: 47). The unfolding spatial experiences of public transport reveal tangible and intangible contextual specificities, including street names, signs, and other space-markers. In a car-thriving context, automobility establishes a system of interaction between driver, car, and infrastructure that influences the commuting experience (Adey et al., 2014: 12). Within such an enduring system, it is difficult to switch ridership to public transport even when alternatives are introduced (Dennis \& Urry, 2009, cited in Adey et al., 2014: 13). This reluctance is even stronger when it comes to informal mobility in unstable contexts, although it presents one approach towards social integration and supports diversity in urban life (Buhr \& McGarrigle, 2017: 228; Blokland \& Schultze, 2017).

Predominant discussions of informal mobility underline its negative perspectives, absence of state endorsement, and response to market demand (e.g. Cervero, 2000; Cervero \& Golub, 2007; Kumar et al., 2016). Informal mobility is obfuscated by transport planners and automobile users who perceive it as a nuisance or undesired reality serving a homogeneous, stereotyped user group rather than acknowledging the "multiple identities of users" (Levy, 2013: 49). Car users perceive it as a safety and pollution threat to be eradicated while overlooking its vital role in providing spatial justice (Cervero, 2000: 9; Adams-Hutcheson et al., 2017; Sheller, 2018). In the absence of strategies within a weak state with weak planning, mobility is affected by instability and abrupt events, leading to coping tactics in order to meet this collective need (Andres, 2013). In such a context, the negative outlook on informal mobility is related to several factors. These could include the "laxly enforced" control over its regulation, degrees of laissez-faire approaches, makeshift or situational solutions, the condition of the existing infrastructure, and the inherited socio-cultural structure, including heavy reliance on the automobile (Cervero, 2000: 3; Rekhviashvili \& Zgibnev, 2020; Weicker \& Sgibnev, 2019).

Organizationally, informal transport is entangled in a power network (Keblowski et al., 2016), which is interconnected vertically to the state and horizontally to informal regulating norms and values (Rekhviashvili \& Zgibnev, 2020). Whereas the government provides licenses, the operators distribute routes, sublet vehicles, and involve a "diverse body of transport workers" (Rekhviashvili \& Zgibnev, 2020: 7). Informal mobility is then negotiated between riders, drivers, operating companies, and the state, under contextual, socio-political considerations going beyond profit-seeking (Rekhviashvili \& Zgibnev, 2020). This negotiation occurs in space and time as an interaction between people, objects, and places. Negotiation is affected by the historically and culturally established system of meanings and values, and it simultaneously generates new meanings and norms (Adey et al., 2014; Salazar, 2018; Rekhviashvili \& Zgibnev, 2020). Under instability, informality acquires a fluid state of behaviour, and thus becomes difficult to disentangle from formality (Roy, 2009b; Watson, 2009).

In summary, unstable contexts lead to disrupted urban environments in which mobility adapts to abrupt changes through tactics, one of which is informal mobility. The latter is used by some groups, providing them with opportunities for diverse spatial experiences. While the stereotyping of riders, and generated norms and values of this system cannot be covered within the scope of this article, other aspects of informal mobility, specifically within an unstable context, are explored. These include some of the material features attributed to informal mobility but also the power relations, inherited culture, and negotiations that affect spatial experiences. Under instability, it is important to explore informal mobility, which creates a dichotomy as a nuisance but also a possible medium for social justice for its users. 


\section{A historical overview of public transportation in Beirut}

In Beirut "infrastructure and sectarian communities are reproduced in the present. Yet without a historical perspective none of this makes sense. For this, we need institutional and infrastructural histories" (Nucho, 2016: 9). These can be briefly summarized as following: Beirut's motorized public transport began with the introduction of a tramway in 1890. Its lines were distributed peripherally along the waterfront and covered Beirut's extents from north to south (Figure 1). Even at the time, tram schedules and stops could not be enforced, reflecting people's fluid practices in stopping coaches indiscriminately (Hanssen, 1998). The tramway, in 1905 followed by the railway and the Beirut port station, witnessed Beirut's growth under Ottoman rule as a nexus between the Middle East and Europe (Hanssen, 1998; Kassir, 2003). This also meant Beirut had a diversified and growing society, characterized by "civic and national identities [that] are multivalent and sharply contested” (Reilly, 2016: 111). Beirut maintained its regional role during the French mandate period, and French planning modelled the city's development, including the expansion of the road network. This network mainly served commercial interests and contributed to the formation of suburban and peri-urban residential areas accommodating separate religious and income groups (Salam, 1998; Saliba, 1998).

The Republic of Lebanon, newly constituted in 1943, was founded on the principles of freemarket economy and consociational government (Salamey \& Tabbar, 2008). A consociational government distributes state roles and power sharing among the various politico-sectarian groups with the purpose of ensuring equity among the multi-sectarian population (Hanf, 1993; Camett, 2011). In reality, “authoritarian inner-state entities”, supported by politico-sectarian parties, prevailed and served their own communities rather than a civic society at large (Salam, 1993; El-Khazen, 2000; Salamey \& Tabbar, 2008: 240; Roy, 2009a). This applied to various facilities, public spaces, and infrastructure, including public transport (Davie, 2001; Mady \& Chettiparamb, 2016; Nucho, 2016; Farjalla et al., 2017). These communities formed "social bonds of cohesion found in tribal, kinship or communitarian solidarities" (Khalaf \& Denoueuz, 1998; Larkin, 2012: 42). The intertwining of governance with sectarianism questioned the "sovereignty to one jurisdiction" (Nucho, 2016: 13) and led to "a fragmented sense of urban identity” (Monroe, 2017: 249). Despite these challenges, convivial living characterized Beirut until the eruption of the civil war.

The new Republic followed and implemented western urban planning trends, mainly influenced by French schemes (Salam, 1998); it prioritized road infrastructure and the automobile (Perry, 2000). These were considered as advantageous to urban development and as a "tool for nationbuilding” (Hass-Klau, 2015; Monroe, 2017: 193). Beirut followed suit and priority was given to expanding the road network at the cost of dismantling the tramway. Particularly in the 1950s and 1960s, the construction of new highways dissected the urban fabric and split neighbourhoods (Tabet, 1996). What followed was an increase in car ownership, neglect of public spaces, and car-driven urban development in and around Beirut (Perry, 2000). Despite the import of buses, the population preferred using shared taxis, or jitneys, called "service". The service's benefit was that it used the existing road network and offered numerous, flexible itineraries. All residential districts were connected by service routes which radiated from the centre, requiring a stop there to change destination (Jouzzy \& Nakkash, 1973). This system served "a wide spectrum of the public" (Jouzzy \& Nakkash, 1973: 324). Even before the war, the "service business [was] linked to politics and their lobby [was] strong" (Jouzzy \& Nakkash, 1973: 325). Meanwhile, controlling the parking, disembarking, and driving behaviour of 
services became a difficult problem for the Beirut municipality: a condition that was normalized and persists to the present day (Chidiac, 2008; Monroe, 2017).

\subsection{War divisions and post-war impact}

In Europe of the 1970s and 1980s, the car-centred approach became contested, and mobility trends were reconsidered. Return to mass-transit became the appropriate solution for urban transport, which could revive urban public spaces and prioritize pedestrians over cars (HassKlau, 2015). However, this period in Lebanon coincided with the beginning of the civil war in 1975: the non-planning period or "urbicide" of Beirut (Fregonese, 2000). The outbreak of the war was symbolically marked by the incident in which a bus crossing between East and West Beirut came under gunfire (Chidiac, 2008). Such incidents recurred during the war, causing an aversion towards buses. "All urban mobility was under the control of various factions who defined their territorial boundaries” (Nucho, 2016: 23). Insecurity generated fear, which in turn formed physical and mental barriers limiting mobility (Nucho, 2016). Except for the service, other public transport was interrupted during the war (Perry, 2000), and buses were reintroduced only after 1994 (CDR, 1995). The war caused the evacuation of the city centre and division of Beirut along a north-south demarcation line along Damascus Road (Tabet, 1996) (Figure 1). This demarcation lasted for 15 years and formed a buffer zone from Martyrs Square in the north within the city centre to the Pine Forest in the south at Beirut's administrative limits. This spatial reconfiguration changed mobility in the divided city. Another war impact was the segregation of Beirut's population into predominantly Christian east and Muslim west (Khalaf, 2002). "Familiar spaces of the city soon became strange and alienating" (Nucho, 2016: 23), and included public spaces such as Martyrs Square, transportation terminals, Damascus road, and the Pine Forest south of the city (Khalaf, 2002: 248; Khalaf, 2006; Mady, 2018a). This change in the city's topology was augmented by the formation of multiple centres around Beirut, with their homogenized neighbourhoods controlled by the politico-sectarian communities and characterized by limited mobility across them (CDR, 1995; Genberg, 2002).

\subsection{Navigating post-war Beirut}

In 1989, the Taif Agreement marked the civil war's end. However, the country continues to undergo intermittent instability. The war led to a publicly mistrusted weak state and the political hegemony of politico-sectarian leaders. The result was a laissez-faire attitude privileging a market-led approach to reconstruction and favouring private interests (Salam, 1998; Khalaf, 2006). On the one hand, the post-war period was marked by the city centre reconstruction under the public-private partnership by the real estate company Solidere . On the other hand, little attention was given to the densification of both East and West Beirut, and to expanding suburbs. One reason for this prioritization was the urgency of reconnecting the war-affected road network with the construction of tunnels and bridges simultaneously connecting and dividing the city (Nucho, 2016). Some examples include the Ring Road circumscribing the reconstructed city centre, the highway along the Beirut River, the Independence Street upgrade to a highway, and the Corniche El Mazraa highway (Figure 1). However, the transportation hub formerly located in Martyrs Square was not reinstated. Instead, two roundabouts respectively in the west and east, Cola and Dora, now served as Greater Beirut's transportation nodes. Everyday mobility of the population was determined by its place of work, residence, and other social practices (Perry, 2000), while Lebanon became the third MENA region country in terms of high car ownership (UITP, 2019). Suburbs and new centres formed part of the Greater Beirut area, with investment and job opportunities located in and around the centre. This pushed the economically disadvantaged population to urban fringes or further outside the city, despite the 
absence of public transport, similarly to other cities sometimes resulting in social exclusion (Perry, 2000; Stanley \& Stanley, 2017; Bou Akar, 2018).

Already prior to, but specifically following the assassination of the former Prime Minister Hariri in 2005, security for politico-sectarian figures was provided at the expense of people's everyday mobility (Fawaz et al., 2009, 2012). In this system, similarly to that of the informal transport, "each claims an element of the 'public' through connections to and integration within state security apparatus, without ever fully submitting to a public authority" (Fawaz et al., 2009: 189). In Beirut, "securitization may be the reflection of the fragmentation of a political system and society that are increasingly compartmentalizing the respective city into territories, each securitized by its own system” (Fawaz et al., 2009: 189). By fragmenting rather than consolidating public good, security practices threatened public spaces and possibilities for encounter, encouraged insular behaviour, and allowed people to navigate the city rather than consider it a meeting place (Fawaz et al., 2009). Fawaz et al. mapped securitized locations in administrative Beirut, indicating variations according to the "level of perceived threat" (2009: 179). These variations were manifested temporally, with fixed or suddenly emerging checkpoints and barriers, police patrols, road closures, or even complete curfews (Monroe, 2011: 91). Being mobile in a highly securitized context meant that the shortest path or the preferred one is not necessarily followed (Bollens, 2012). Depending on the occasion, one develops a mobility tactic.

On top of security measures that impacted traffic congestion, mobility varied according to people's perceptions of security, their politico-sectarian affiliations, as well as their socioeconomic class (Samaha \& Mohtar, 2016). While Beirut's residential neighbourhoods are socio-economically mixed (Alaily-Matar, 2008), they are characterized by homogeneity in terms of the politico-sectarian belonging of their populations, traversing some city parts while avoiding others. For car users in these neighbourhoods, mobility choices vary along politicosectarian differences. Additionally, in Beirut and its suburbs, along with changing demographics, the intersections of “different politico-religious territories” (Fawaz et al., 2009: 181) necessitated divisions with the purpose of securitization. These made the city unequally accessible at any time, depending on one's place of residence (Borell, 2008; Fawaz et al., 2009; Bou Akar, 2012; Deeb \& Harb, 2013). This meant that Beirut was "subjected to overlapping, sometimes conflicting security systems that neither report to the same authority nor concur on their identification of what constitutes a threat" (Fawaz et al., 2009: 189). This intertwining of actors and actions over space and time affected infrastructure and "sectarian geographies" in Beirut's urban spaces (Nucho, 2016: 3), and consequently mobility. Therefore, "being mobile in Beirut is a civic practice, one in which different social and territorial boundaries are fashioned" (Monroe, 2011: 107). The effect is differentiation and inequalities depending on one’s location and politico-sectarian belonging (Monroe, 2011: 92).

Despite these circumstances, mobility persisted in unstable yet vibrant Beirut. A shared realization for the need to provide mobility was present, as reflected by the requests of some taxi and bus drivers to the government to organize public transport (Baaj, 2008; CDR, 2018). This was also evident in the responses to a BRT survey indicating the population's request for public transport, since it would provide "a chance to meet new people" (CDR, 2018: 236). With this imminent mobility need, the Riders Rights NGO took the initiative to generate a map for the informal bus system and facilitate its use for riders (Mady, 2018b). 


\section{The infiltration of informal mobility}

In 1996, after the end of the war, a bus network was proposed, and the state Office for Railway and Shared Transport (French acronym OCFTC) implemented a plan for reinstating public buses, operating on 22 routes without dedicated lanes and with bus stops that would soon be vandalized (Mady, 2020). In the absence of the Martyrs Square hub, OCFTC buses did not have terminals, and were instead served by city edge terminals at Cola and Dora roundabouts (Chidiac, 2008). With the uncontrolled expansion of the suburbs, Beirut's administrative edges merged with these polycentres, in addition to already polarized east and west neighbourhoods. Cheaper than taxis and services, and for an initial post-war limited demand, bus transport was provided by the OCFTC, with a limited number of operating buses, and amidst traffic congestion in a securitized and car-privileged urban context (Baaj, 2008). Gradually, families with affiliations to politico-sectarian leaderships entered the bus transport system. With the limited OCFTC buses, the newcomers dominated routes, leading to the emergence of what is referred to as unregulated or artisanal transport (Chidiac, 2008; Nucho, 2016; Nakkash, 2017). Providing informal transport required low capital investment for a needed and to some extent lucrative business (CDR, 2018).

\subsection{Characteristics and negotiations}

This infiltration into the public transport system was enabled by two aspects: the licensing mechanism and the absence of a single transportation authority (Chidiac, 2008). The Parliament issued licenses, or "red plates", to individuals, not vehicles, while the Ministry of Interior registered vehicles and controlled them through the traffic police. The same red plates were used by different taxi companies, services, vans, or buses, including the OCFTC ones. The red plates were distributed by quotas to politico-sectarian leaders, who support their communities rather than the public at large. Van and bus companies with fleets generally manufactured in the early 2000s obtained licences, used the same road infrastructure and routes as OCFTC buses, and operated at minimum cost (CDR, 2018). Buses were serviced by community mechanics and petrol stations, and their operators hired precarious drivers receiving minimal wages.

In terms of operation, the system reflected a blurring of boundaries between formal and informal mobility, in which infrastructure, vehicles, and operations intertwine (Mady, 2018b). The result was an interconnected horizontal and vertical management of the system. This is reflected in licensing red plates, the "laxly enforced" rules of stationing, routes and service zones, and the politico-sectarian supported operators. One example of such company is LCC (Lebanon Commuting Company), which was affiliated to the then-Prime Minister Rafic Hariri (Chidiac, 2008). The system included various operation models: a single vehicle type operation along a route, one operator with a fleet along one or more routes, cooperatives of more than one fleet, or companies (Faraj \& Baaklini, interview, June 2018; Faraj, interview, May and August 2019, March 2021). Some buses have tickets, and controllers who check whether passengers have bought them, while others operate without tickets (Faraj, interview, August 2019). These operation criteria enable the competitive presence in the network vis-à-vis OCFTC (Takyi, 1990). Such a state of affairs is not only a response to demand but also reflects embeddedness in the underlying fragmented politico-sectarian community. Within this context, infrastructure “could stretch across 'overlapping jurisdictions' and boundaries”, reflecting “entanglement between political actors who operate simultaneously in multiple scales and institutional spaces" (Nucho, 2016: 8). 
After the war, the number of red plates both legal and counterfeit increased significantly (Chidiac, 2008), leading to an oversupply of vehicles on some routes (Baaj, 2008). Several syndicates corresponding to different politico-sectarian communities were formed for services, taxis, buses, and later on, vans. The purpose of these multiple syndicates was to redistribute coverage of zones with minimal overlap and conflict across the politico-sectarian operators serving their respective communities (Faraj, interview, August 2019). The fragmentation of the public transport management over several administrations and departments rendered this sector difficult to control, as was the case even before the war (Jouzzy \& Nakkash, 1973; Chidiac, 2008). This reflects how divides, whether inherited or emerging, are entrenched in various social practices, including both the operation of the shared transport system and the spatial experience of the system's riders.

\subsection{Beirut's street network configuration and informal mobility}

For the purposes of the present research, the available bus map - www.busmap.me - served to identify the lines that would cover an itinerary from the original location in north-eastern suburbs to the destination in Beirut city centre in the following sequence: buses $6,24,12,2$, and finally 22. In practice, the reality of the journey turned out to diverge from the plan as bus number 6 deviated from its itinerary before arriving to Cola. This necessitated an interchange from its new terminal stop with bus number 15 in order to arrive at Cola Roundabout. Below is a brief description of the routes, while the major stops along them are indicated in Figure 1.

-Bus number 2 connects Antelias, an eastern suburb, to Hamra, a sector in West Beirut with medical, educational, cultural, and administrative services. This bus alternates with number 5, which connects Hamra to Ain Saadeh, another eastern suburb. It does not allow for easy transfers within the southern part of Beirut.

-Bus number 6 connects Nahr el Mot, a major traffic junction in an eastern suburb, to the Kuwait Embassy, which is located at a major traffic node just south of administrative centre of Beirut. This bus does not have a stop that would allow riders to transfer to the southeastern suburbs.

-Bus number 15 is divided into two lines: one starts from Nahr el Mot, and connects to Dora and then Ain Mreisseh in West Beirut. The other number 15 arrives to Cola, serving areas outside Beirut, including areas to the south-east of the city, Aleyh and Kmetiyeh, passing along the way to Cola by the Kuwaiti Embassy and the Sports City nodes. The two lines meet at Cola, otherwise having different itineraries.

-Bus number 22 connects Dora to Baabda in the south-eastern suburbs. It is operated by both OCFTC and private operators, yet they have different stops at Dora. This line has no connection to Cola or other major nodes in the western part of Beirut.

-Bus number 24 operates within Beirut from Hamra in the west to Badaro in the east, then to Furn el Chebback, an eastern suburb. However, it does not intersect with number 6 to provide a direct connection to Dora or other nodes in the eastern suburbs.

The practical journey served to validate how suburbs are not directly connected to the city centre, especially in the absence of a terminal at Martyrs Square. The available option for riders coming from either the southern or north-eastern suburbs is to exchange at Cola or Dora respectively, in order to arrive at destinations within Beirut (Mady, 2020). As demonstrated in the itinerary, few routes covering the north-eastern suburbs reach the southern suburbs or vice versa (Figure 1). The informal bus system follows OCFTC routes along which some of the OCFTC buses are still in service, such as bus number 22. This often leads to conflicts between drivers racing to pick up passengers. As informed by Faraj (interview, March, 2021), these bus 
routes are managed by diverse private operators serving their respective communities. Buses connecting different areas operate along routes when there is a relation between the communities living in both areas; for instance, residing in one area but having commercial activities or job opportunities in the other (Faraj \& Baaklini, interview, June 2018; Faraj, interview, March 2021). Examples include bus lines 6 and 15, where the numbers are duplicated and function along separate routes to serve different communities. In order to acquire a more comprehensive understanding of this network, further investigation on other bus lines is required.
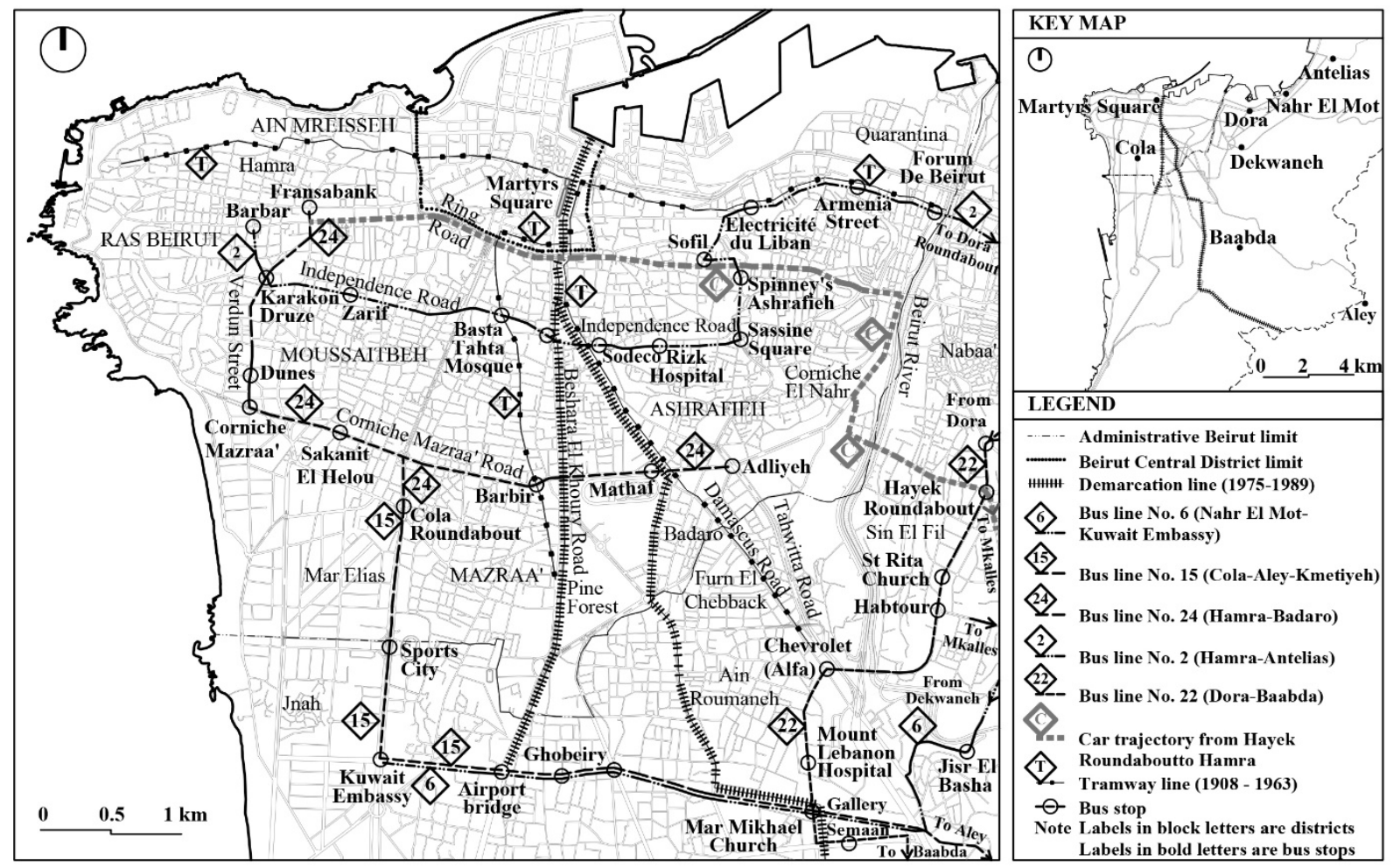

Figure 1: Map indicating the bus routes followed to move across Beirut (illustration: Christine Mady).

\subsection{Mobility experiences under instability}

Regarding bus stops, as indicated on the Riders Rights’ Bus Map (www.busmap.me; Figure 1), it is evident that the marked stops are indicative of locations with affordances which may act as stops (Mady, 2020). Based on observations, this allows riders to request disembarking at any location along the route. Likewise, this flexibility allows the driver to deviate from the mapped route or even alter the terminal stop. Adaptations happen in cases of road repair works, bringing a rider closer to their destination, or avoiding temporary checkpoints, as experienced with bus number 6 (Mady, 2020). Therefore, the system's adaptability to sudden events could change the riders' spatial experience. More empirical work, however, is required for validation.

Navigating Beirut entails "a profoundly social experience” in which people actively learn by asking others (Nucho, 2016: 24). One has to ask to discover which line stops at which location or terminal as only few stops are visually defined or clearly marked (Mady, 2020). A terminal is an empty strip, or even a vacant lot adjacent to the main road, and could be shared by more than one operator, such as lines 2 and 5 . Despite expectations that physically reconnecting the post-war city would heal the east-west divide, this process was mentally obstructed and 
powered by collective memories (Larkin, 2012), which guided navigation in the city and provided indication of places to avoid (Genberg, 2002; Chidiac, 2008; Saksouk-Sasso, 2015; Nucho, 2016; Mady, 2018a). This emphasizes a context "where national sovereignty is heavily contested" and security privatized (Fawaz et al., 2009: 188). The various fragmented areas or zones are supported by spatial markers, which are not only fixed but also mobile as some buses have religious slogans and symbols displayed at the front of the bus. Also, religious ornaments worn by the driver, controller and riders, or various dress codes pertaining to cultural or religious groups were observed. Therefore, even if a vehicle of the informal bus network operates in another zone, its particular identity is manifested and can be recognized by stickers, slogans, and symbols (Chidiac, 2008). Similarly, as one traverses different divided city parts, one notices politico-sectarian slogans, symbols, and images of leaders, which have both become an integral and yet dynamically changing part of the city, thus affecting communities' comfort zones (Mady, 2020).

In summary, Beirut's informal bus system follows similar trends to its counterparts in other cities. This applies to the vertical and horizontal power relations, the local culture entrenched in serving communities and market interests, and the informal mobility's makeshift solutions. The outlined journey served to show how existing infrastructure, which follows spatial partitioning established after the war, has affected the routes of the informal bus system. Additionally, the spatially defined segregated communities generate part of the demand for this informal mobility and manage only marginally to break war-time divisions. In operating this system, and despite abrupt changes, instability leads to the system's fluidity and adaptability, allowing for mobility of people with a diversity of urban experiences. Although considered as a nuisance, the system is worth exploring further for its possible positive impact on social integration and urban diversity.

\section{Conclusion}

The present article explored the state of informal mobility within Beirut's unstable context, and its impact on riders' differentiated experiences, especially when commuting between Beirut's formerly divided east and west parts. This exploration was embedded in Beirut's history and the developmental stages of its public transportation from the $19^{\text {th }}$ century to the end of the civil war. Over time, perpetual instability generated new divides and defined new zones within Beirut. These are reflected materially and immaterially across the city in urban spaces, infrastructure, facilities and neighbourhoods, and the relations between various actors. People's propensity to move across divides is guided by security, collective memory, and their individual politico-sectarian affiliations. This mobility could be differentiated for car users or bus riders as demonstrated in the chosen itinerary. The article suggests that informal mobility in Beirut contributes to a differentiated social and spatial experience, while the system's adaptability enables it to respond to the context's intermittent instability. The informal bus system, embedded in contextual specificities and entrenched in the consociational structure, has its limitations. Rather than reverting to the pre-war mobility pattern radiating from the city centre, it perpetuates some of the inherited divides. However, it also allows the fragmented society to collaborate, with encounters and social interactions occurring while commuting. Learning from the riders could contribute to a more integrative mobility system in Beirut, which could in turn affect its spatial practices. The present article sets the basis for further empirical work covering all of the bus routes, with the purpose of reinforcing the system's potential positive contribution. 
Christine Mady, Department of Architecture, Notre Dame University-Louaize, Zouk Mosbeh, Lebanon (christine.mady@ndu.edu.lb)

\section{Acknowledgements}

The author would like to thank Jessica Lahoud for her support in preparing the map.

\section{References}

Adams-Hutcheson, G. et al. (2017) Introduction: Understanding mobility in a dangerous world. Transfers, 7(3), pp. 1-5. DOI: 10.3167/TRANS.2017.070302

Adey, P., Bissel, D., Hannam, K., Merriman, P. \& Sheller, M. (eds.) (2014) The Routledge handbook of mobilities. London and New York, Routledge. DOI: 10.4324/9781315857572

Alaily-Mattar, N. (2008) Beyond gated communities? Detachment and concentration in networked nodes of affluence in the city of Beirut. Urban Design International, 13(4), pp. 263-271. DOI: $10.1057 /$ udi.2008.30

Andres, L. (2013) Differential spaces, power hierarchy and collaborative planning: a critique of the role of temporary uses in shaping and making places. Urban Studies, 50(4), pp. 759-775. DOI: $10.1177 / 0042098012455719$

Baaj, M. H. (2008) The public land transport sector in Lebanon. Journal of Public Transportation, 3(3), pp. 87108. DOI: $10.5038 / 2375-0901.3 .3 .5$

Blokland, T. (2017) The public life of social capital. In: Hall, S. and Burdett, R. (eds.) The SAGE handbook of the $21^{\text {st }}$ century city, pp. 552-566. London, SAGE Publications. DOI: 10.4135/9781526402059.n30

Blokland, T. \& Schultze, H. (2017) Belonging, conviviality or public familiarity? Making sense of urbanity in rapidly transforming neighbourhoods through the lens of Berlin and Rotterdam. In: Smagacz-Poziemska, M., Frysztacki, K. \& Bukowski, A. (eds.) Reimagining the city: municipality and urbanity today from a sociological perspective, pp. 243-264. Kraków, Jagiellonian University Press.

Bollens, S. A. (2012) City and soul in divided societies. New York, Routledge. DOI: 10.4324/9780203156209

Borell, K. (2008) Terrorism and everyday life in Beirut 2005: Mental reconstructions, precautions and normalization. Acta Sociologica, 51(1), pp. 55-70. DOI: 10.1177/0001699307086818

Bou Akar, H. (2012) Contesting Beirut’s frontiers. City \& Society, 24(2), pp. 150-172. DOI: 10.1111/j.1548744X.2012.01073.x

Bou Akar, H. (2018) For the war yet to come: Planning Beirut's frontiers. Stanford, CA, Stanford University Press. DOI: 10.1515/9781503605619

Buhr, F. (2017) A user's guide to Lisbon: Mobilities, spatial apprenticeship and migrant urban integration. Mobilities, 13(3), pp. 337-348. DOI: 10.1080/17450101.2017.1368898

Buhr, F. \& McGarrigle, J. (2017) Navigating urban life in Lisbon: A study of migrants' mobilities and use of space. Social Inclusion, 5(4), pp. 226-234. DOI: 10.17645/si.v5i4.1105

Camett, M. C. (2011) Partisan activism and the access to welfare in Lebanon. Studies in Comparative International Development, 46(1), pp. 70-97. DOI: 10.1007/s12116-010-9081-9

Cervero, R. (2000) Informal Transport in the Developing World. Nairobi, UN-Habitat.

Cervero, R. \& Golub, A. (2007) Informal transport: A global perspective. Transport Policy, 14(6), pp. $445-457$. DOI: $10.1016 /$ j.tranpol.2007.04.011

Chidiac, R. (2008) Le transport artisanal dans un contexte de crise politique, le ACS du Liban. In: Godard, X. (ed.) Le transport artisanal dans les villes de la Méditerranée, pp. 41-60. Les collectes de l’INRETS (Institut National de Recherche sur les Transports et leur Sécurité). Paris, INRETS, № 114.

Council for Development and Reconstruction (CDR) (1995) Greater Beirut transportation plan. Beirut, Republic of Lebanon, CDR.

Council for Development and Reconstruction (CDR) (2018) Environmental and social impact assessment (ESIA) for the bus rapid transit (BRT) system between Tabarja and Beirut and feeder buses services (prepared by ELARD and EGIS). Beirut, Republic of Lebanon, CDR.

Davie, M. (2001) Beyrouth 1825-1975: un siècle et demi d'urbanisme. Beirut, Publications de l'Ordre des Ingénieurs et Architectes de Beyrouth.

de Certeau, M. (1984) The practice of everyday life. Berkeley, Los Angeles, CA, London, University of California Press.

Deeb, L. \& Harb, M. (2013) Leisurely Islam: Negotiating geography and morality in Shi'ite South Beirut. Princeton, NJ and Oxford, Princeton University Press.

DOI: 10.23943/princeton/9780691153650.001.0001

Dennis, K. \& Urry, J. (2009) After the car. Cambridge, Polity Press.

El-Khazen, F. (2000) The breakdown of the state in Lebanon. Cambridge, Mass., Harvard University Press. 
Evans, J., O'Brien, J. \& Ch Ng, B. (2018) Towards a geography of informal transport: Mobility, infrastructure and urban sustainability from the back of a motorbike. Transactions of the Institute of British Geographers, 43(4), pp. 674-688. DOI: 10.1111/tran.12239

Faraj, C. (2021) Informal mobility in Beirut (interview, 3 March, 2021).

Faraj, C. (2019) Informal mobility in Beirut (interview, 8 August, 2019).

Faraj, C. (2019) Informal mobility in Beirut (interview, 20 May, 2019).

Faraj, C. \& Baaklini, J. (2018) Informal mobility in Beirut (interview, 14 June, 2018).

Farjalla, N. et al. (2017) The role of informal systems in urban sustainability and resilience - a review. Report by the Issam Fares Institute for Public Policy and International Affairs, American University of Beirut, Beirut.

Fawaz, M., Harb, M. \& Gharbiyeh, A. (2012) Living Beirut's security zones: An investigation of the modalities and practice of urban security. City \& Society, 24(2), pp. 173-195.

Fawaz, M., Harb, M. \& Gharbiyeh, A. (eds.) (2009) Beirut: Mapping security. Beirut, Diwan.

Fregonese, S. (2009) The urbicide of Beirut? Geopolitics and the built environment in the Lebanese civil war (1975-1976). Political Geography, 28(5), pp. 309-318. DOI: 10.1016/j.polgeo.2009.07.005

Genberg, D. (2002) Borders and boundaries in post-war Beirut. In: Erdentug, A. \& Colombijn, F. (eds.) Urban ethnic encounters: The spatial consequences, pp. 81-96. London, Routledge.

Godard, X. (2008) Le transport artisanal dans les villes de la Méditerranée. Les collectes de l’INERT (Institut National de Recherche sur les Transports et leur Sécurité). Paris, Actes INRETS, N 114.

Hanf, T. (1993) Coexistence in wartime Lebanon: Decline of a state and rise of a nation. London, Centre for Lebanese Studies in association with I. B. Tauris.

Hanssen, J. (1998) "Your Beirut is on my desk". Ottomanizing Beirut under sultan Abdülhamid II (1876-1909). In: Rowe, P. \& Sarkis, H. (eds) Projecting Beirut: Episodes in the construction and reconstruction of a modern city, pp. 41-67. Munich, London, New York, Prestel.

Hass-Klau, C. (2015) The pedestrian in the city. New York, London, Routledge. DOI: 10.4324/9780203067390

Jouzzy, N. \& Nakkash, T. (1973) The use of the passenger car for public transit. In: Proceedings of the International Conference on Transportation Research, Bruges, Belgium, pp. 321-328.

Kassir, S. (2003) Tarikh Beirut [Beirut’s History], $1^{\text {st }}$ edition. Beirut, Dar An-Nahar.

Khalaf, S. (2002) Civil and uncivil violence in Lebanon: A history of internationalization of communal conflict. New York, Columbia University Press. DOI: 10.7312/khal12476

Khalaf, S. (2006) Heart of Beirut: Reclaiming the Bourj. London, Saqi Books.

Khalaf, S. \& Denoueuz, G. (1998) Urban networks and political conflict in Lebanon. In: Shehadi, N. and Haffar Mills, D. (eds.) Lebanon: A history of conflict and consensus, pp. 181-200. London, I.B. Tauris.

Keblowski, W., Bassens, D. \& van Criekingen, M. (2016) Re-politicizing transport with the right to the city: An attempt to mobilise critical urban transport studies. Cosmopolis Working Paper. Vrije Universiteit Brussel, Cosmopolis, Brussels.

Knierbein, S. \& Tornaghi, C. (2015) Relational public space: New challenges for architecture and planning education. In: Tornaghi, C. \& Knierbein, S. (eds.) Public space and relational perspectives: New challenges for architecture and planning, pp. 1-11. London, New York, Routledge. DOI: $10.4324 / 9781315750729$

Kumar, M. et al. (2016) Informal public transport modes in India: A case study of five city regions. International Association of Traffic and Safety Sciences Research, 39(2), pp. 102-109. DOI: 10.1016/j.iatssr.2016.01.001

Larkin, C. (2012) Memory and conflict in Lebanon: Remembering and forgetting the past. Abingdon , New York, Routledge. DOI: 10.4324/9780203137970

Leese, M. \& Wittendorp, S. (2018) The new mobilities paradigm and critical security studies: Exploring common ground. Mobilities 13(2), pp. 171-184. DOI: 10.1080/17450101.2018.1427016

Levy, C. (2013) Travel choice reframed: "Deep distribution” and gender in urban transport. Environment and Urbanization 25(1), pp. 47-63. DOI: 10.1177/0956247813477810

Mady, C. (2018a) Public space activism in unstable contexts: Emancipation from Beirut's postmemory. In: Knierbein, S. \& Viderman, T. (eds.) Public space unbound: Urban emancipation and the post-political condition, pp. 189-206. Abingdon, New York, Routledge. DOI: 10.4324/9781315449203-13

Mady, C. (2018b) Everyday mobility in Beirut: Reassessing informal transport. Master's Program Infrastructure Planning $3^{\text {rd }}$ Conference, 25-28 September, pp. 95-110. Stuttgart, University of Stuttgart.

Mady, C. (2020) Experiencing mobility under instability: A perspective from Beirut's informal bus riders. City Street ${ }^{4}$ Conference: Streets for 2030: Proposing streets for integrated and universal mobility, 23 September, pp. 414-423. Ljubljana, University of Ljubljana, Faculty of Architecture and Urban Planning Institute of the Republic of Slovenia.

Mady, C. \& Chettiparamb, A. (2016) Planning in the face of 'deep divisions': A view from Beirut, Lebanon. Planning Theory 1(23), pp. 296-317. DOI: 10.1177/1473095216639087 
Medeiros, R. M. et al. (2018) Merging ICT and informal transport in Jakarta’s oejk system. Transportation Planning and Technology, 41(3), pp. 1-17. DOI: 10.1080/03081060.1435465

Mom, G. (2017) Editorial. Transfers, 7(3), pp. vii-x. DOI: 10.3167/TRANS.2017.070301

Mom, G. \& Clarsen, G. (2017) Editorial. Transfers, 7(1), pp. 1-3. DOI: 10.3167/TRANS.2017.070101

Mom, G., Clarsen, G., Kim, N., Seiler, C., Moeser, K., Mueller, D., Terranova, C. \& Volti, R. (2011) Editorial. Transfers, 1(1), pp. 1-13. DOI: 10.3167/trans.2011.010201

Monroe, K. V. (2011) Being mobile in Beirut. City and Society, 23(1), pp. 91-111. DOI: 10.1111/j.1548744X.2011.01050.x

Monroe, K. V. (2017) Circulation, modernity, and urban space in 1960s Beirut. History and Anthropology, 28(2), pp. 188-201. DOI: 10.1080/02757206.2017.1279613

Nakkash, T. (2017) Towards regulated public transport for Lebanon: Overcoming obstacles and rectifying concepts, (public lecture, 25 October, translated from Arabic). Beirut, Order of Engineers and Architects.

Nemeth, J. (2010) Security in public space: An empirical assessment of three US cities. Environment and Planning A, 42(10), pp. 2487-2507. DOI: 10.1068/a4353

Nemeth, J. \& Hollander, J. (2010) Security zones and New York City’s shrinking public space. International Journal of Urban and Regional Research, 34(1), pp. 20-34. DOI: 10.1111/j.1468-2427.2009.00899.x

Nucho, J. R. (2016) Everyday sectarianism in urban Lebanon: Infrastructures, public services and power. Princeton, NJ, Princeton University Press. DOI: 10.23943/princeton/9780691168968.001.0001

Perry M. (2000) Car dependency and culture in Beirut: Effects of an American transport paradigm. Third World Planning Review, 22(4), pp. 395-409. DOI: 10.3828/twpr.22.4.k372318t225x243u

Reilly, J. A. (2016) The Ottoman cities of Lebanon: Historical legacy and identity in modern Middle East. London, New York, I. B. Tauris. DOI: 10.5040/9781350989030

Rekhviashvili, L. \& Sgibnev, W. (2020) Theorising informality and social embeddedness for the study of informal transport. Lessons from the marshrutka mobility phenomenon. Journal of Transport Geography, 88. Available at: https://www.sciencedirect.com/science/article/pii/S0966692317306531 (accessed 1 Mar. 2019). DOI: 10.1016/j.jtrangeo.2019.01.006

Roy, A. (2009a) Civic governmentality: The politics of inclusion in Beirut and Mumbai. Antipode, 41(1), pp. 159-179. DOI: 10.1111/j.1467-8330.2008.00660.x

Roy, A. (2009b) Why India cannot plan its cities: Informality, insurgence and the idiom of urbanization. Planning Theory, 8(1), pp. 76-87. DOI: 10.1177/1473095208099299

Saksouk-Sasso, A. (2015) Making spaces for communal sovereignty: The story of Beirut's Dalieh. Arab Studies Journal, 23(1), pp. 296-318.

Salam, A. (1998) The role of government in shaping the built environment. In: Rowe, P. \& Sarkis, H. (eds.) Projecting Beirut: Episodes in the construction and reconstruction of a modern city, pp. 122-33, Munich, London, New York, Prestel.

Salam, A. (1993) Lebanon's experience with urban planning: Problems and prospects. In: Khalaf, S.\& Khoury, P. (eds.) Recovering Beirut: Urban design and post war reconstruction, pp. 194-201. Leiden, Brill.

Salamey, I. \& Tabbar, P. (2008) Consociational democracy and urban sustainability: Transforming the confessional divides in Beirut. Ethnopolitics, 7(2-3), pp. 239-263. DOI: 10.1080/17449050802243350

Salazar, N. (2018) Theorizing mobility through concepts and figures. Tempo Social, revista de sociologia da USP, 30(2), pp. 153-168. DOI: 10.11606/0103-2070.ts.2018.142112

Saliba, R. (1998) Beirut 1920-1940: Domestic architecture between tradition and modernity. Beirut, Order of Engineers and Architects.

Samaha, P., \& Mohtar, A. (2016) Decoding an urban myth: An inquiry into the socio-economics of van number 4 in Beirut. DOI 10.13140/RG.2.1.2536.3602

Sheller, M. (2014) Sociology after the mobilities turn. In: Adey, P, Bissel, D., Hannam, K., Merriman, P. \& Sheller, M. The Routledge handbook of mobilities, pp. 45-54. London, New York, Routledge.

Sheller, M. (2018) Theorizing mobility justice. Tempo Social, revista de sociologia da USP, 30(2), pp. 17-34. DOI: $10.4324 / 9780815377047-2$

Stanley, J. \& Stanley, J. (2017) The Importance of Transport for Social Inclusion. Social Inclusion, 5(4), pp. 108-115. DOI: 10.17645/si.v5i4.1289

Tabet, J. (1996) Al-I'maar wal-masslaha al-a'amah [Reconstruction and the public good]. Beirut, Dar Al-Jadid.

Takyi, I. K. (1990) An evaluation of jitney systems in developing countries. Transportation Quarterly, 44(1), pp. 163-177.

UITP MENA Centre for Transport Excellence (2019) MENA transport report 2019. Dubai, UITP MENA CTE.

Urry, J. \& Sheller, M. (2006) The new mobilities paradigm. Environment and Planning A 38(2), pp. $207-226$. DOI: $10.1068 / a 37268$

UN-Habitat (2018) National urban policies programme in Lebanon: Diagnosis report. Beirut, UN-Habitat.

Watson, V. (2009) Seeing from the South: Refocusing urban planning on the globe's central urban issues. Urban Studies, 46(11), pp. 2259-2275. DOI: 10.1177/0042098009342598 
Weicker, T. \& Zgibnev, W. (2019) Infrastructures as fluidities: How marshrutkas help us to overcome static conceptions of road-based mobility service provision. In: Tuvikene, T., Sgibnev, W. \& Neugebauer, C. S. (eds.) Post-socialist urban infrastructure, pp. 195-212. London, New York, Routledge. DOI: 10.4324/9781351190350-12

World Bank (2017) Greater Beirut urban transport project: Project information document/integrated safeguards data sheet (PID/ISDS). Washington, World Bank.

World Bank (2016) General Beirut urban transport. Project information document (PID): Concept stage. Washington, World Bank.

Yip, N. M., Forrest, R. \& Xian, S. (2016) Exploring segregation and mobilities: Application of an activity tracking app on mobile phone. Cities, 59(11), pp. 156-163. DOI: 10.1016/j.cities.2016.02.003 